JRNAL ПMПAH

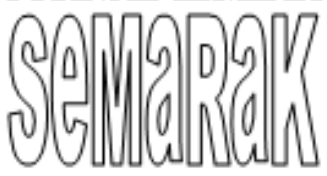

P-ISSN 2615-6849, E-ISSN 2622-3686

Jurnal Semarak,Vol.4,No.2,Juni 2021, Hal (8-30)

\title{
PENGARUH KINERJA KEUANGAN PERUSAHAAN DENGAN RASIO KEUANGAN TERHADAP NILAI PERUSAHAAN
}

\author{
Indawati, Anggun Anggraini \\ Staf Pengajar Fakultas Ekonomi Universitas Pamulang \\ dosen universitas pamulang, email : dosen02151@unpam.ac.id, \\ dosen02156@unpam.ac.id
}

\begin{abstract}
ABSTRAK
Tujuan dari penelitian ini adalah untuk mengetahui pengaruh rasio likuiditas, rasio solvabilitas, rasio aktivitas dan rasio profitabilitas terhadap kinerja keuangan perusahaan manufaktur subsektor industry logam yang terdaftar di Bursa Efek Indonesia (BEI). Populasi penelitian ini adalah perusahan manufaktur sub industry logam yang terdaftar di Bursa Efek Indonesia dari tahun 2016-2019. Dalam penelitian ini, 52 sampel dari 13 perusahaan diambil sampelnya dengan menggunakan metode purposive sampling dan diamati selama 4 tahun. Dalam penelitian ini, teknik analisis regresi linear berganda digunakan dalam aplikasi e-views 9. Hasil penelitian menunjukkan bahwa rasio likuiditas, rasio solvabilitas, rasio aktivitas dan rasio profitabilitas dengan tingkat signifikan $0.00000<0.05$ berpengaruh secara simultan terhadap nilai perusahaan. Kinerja keuangan perusahaan dengan rasio likuiditas dengan tingkat signifikansi $0.2553<0.05$ tidak berpengaruh terhadap nilai perusahaan. Kinerja keuangan dengan rasio solvabilitas dengan tingkat signifikansi $0.00000<0.05$ berpengaruh terhadap nilai perusahaan. Kinerja keuangan dengan rasio aktivitas dengan tingkat signifikansi $0.9994>0.05$ tidak berpengaruh terhadap nilai perusahaan. Kinerja keuangan dengan rasio profitabilitas dengan tingkat signifikansi $0.3751>0.05$ tidak berpengaruh terhadap nilai perusahaan.
\end{abstract}

Kata Kunci: Kinerja keuangan, Rasio Likuiditas, Rasio Solvabilitas, Rasio Aktivitas, Rasio Profitabilitas, Nilai Perusahaan

\begin{abstract}
The purpose of this study was to determine the effect of liquidity ratios, solvency ratios, activity ratios and profitability ratios on the financial performance of metal industry sub-sector manufacturing companies listed on the Indonesia Stock Exchange (BEI). The population of this research is metal sub-industry manufacturing companies listed on the Indonesia Stock Exchange from 2016-2019. In this study, 52 samples from 13 companies were sampled using purposive sampling method and observed for 4 years. In this study, multiple linear regression analysis techniques were used in the e-views 9 application. The results showed that the liquidity ratio, solvency ratio, activity ratio and profitability ratio with a significant level of $0.00000<0.05$ had a simultaneous effect on firm value. The company's financial performance with a liquidity ratio with a significance level of 0.2553 $<0.05$ has no effect on firm value. Financial performance with a solvency ratio with a significance level of $0.00000<0.05$ has an effect on firm value. Financial performance with an activity ratio with a significance level of 0.9994>0.05 has no effect on firm value. Financial performance with a profitability ratio with a significance level of $0.3751>0.05$ has no effect on firm value.
\end{abstract}


Keywords: Financial performance, Liquidity Ratio, Solvency Ratio, Activity Ratio, Profitability Ratio, Firm Value

\section{PENDAHULUAN}

\subsection{Latar Belakang}

Tujuan utama perusahaan yaitu memaksimalkan nilai perusahaan. "Nilai perusahaan merupakan persepsi investor terhadap perusahaan yang sering dikaitkan dengan harga saham". Pencapaian nilai perusahaan yang tinggi juga menjadi tujuan perusahaan yang mengoptimalkan harga saham untuk masuk kepasar modal, agar perusahaan terus berlanjut (sustainable) dengan strategi pencapaiaan yang maksimal maka perusahaan harus selalu melakukan pengembangan dalam kinerja perusahaan yang dimana dapat mempengaruhi persepsi para Investor terhadap perusahaan. Memaksimalkan nilai perusahaan adalah tujuan utama perusahaan atau induk perusahaan yang sangat penting bagi perusahaan.

Nilia perusahaan yang tinggi membuat pasar modal percaya dengan situasi saat ini dan prospek perusahaan dimasa depan. Dapat dikatakan semakin tinggi nilai perusahaan maka akan berdampak pada makin besarnya kemakmuran pemegang saham atas perusahaan. "Nilai perusahaan yang dapat diukur dengan Price Book Value merupakan perbandingan antara harga pasar dengan nilai buku saham (Husnan dan Pudjiastuti, 2013:258)".

Faktor utama yang dapat memperngaruhi nilai perusahaan yakni kinerja keuangan perusahaan, ini sangat penting dilakukan sebagai sarana atau indikator dalam rangka memperbaiki kegiatan operasional perusahaan sehingga diharapkan perusahaan dapat mengalami pertumbuhan keuangan yang sehat dan lebih baik lagi, dalam menunjukkan kondisi suatu perusahaan.
Pelaporan keuangan suatu perusahaan hanya sebagai alat untuk menilai pekerjaan departemen akuntansi dan laporan keuangan selanjutnya bukan hanya alat untuk menilai tetapi juga dasar untuk menentukan atau menilai posisi keuangan perusahaan. Penilaian terhadap kinerja keuangan perusahaan penting dilakukan sebagai sarana atau indikator dalam rangka memperbaiki kegiatan operasional perusahaan sehingga diharapkan perusahaan dapat mengalami pertumbuhan keuangan yang lebih baik dan juga dapat bersaing dengan perusahaan lain.

Analisis rasio keuangan merupakan salah satu alat analisis yang sering digunakan dalam melakukan penilaian terhadap kinerja keuangan perusahaan. Rasio keuangan merupakan angkaangka yang diperoleh dengan melakukan perbandingan pada pos-pos yang ada pada laporan keuangan. Secara umum, rasio keuangan terdiri dari rasio likuiditas, rasio solvabilitas, rasio aktivitas, rasio profitabilitas, rasio pertumbuhan dan rasio penilaian.

Analisis rasio keuangan dengan rasio likuiditas dapat mempengaruhi atas nilai perusahaan karena dengan rasio likuiditas dapat menggambarkan kemampuan perusahaan dalam memenuhi kewajiban jangka pendek dan memenuhi kewajiban yang akan jatuh tempo baik kewajiban kepada pihak luar perusahaan atau likuiditas badan usaha maupun didalam perusahaan atau likuiditas perusahaan. Selain rasio likuiditas ada juga rasio solvabilitas yang dapat mempengaruhi nilai perusahaan karena dengan rasio solvabilitas dapat digunakan untuk mengukur berapa banyak hutang yang dapat dibayar Kembali oleh asset 
JRNAL ПММАH

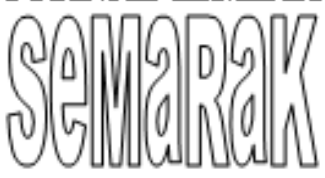

P-ISSN 2615-6849, E-ISSN 2622-3686

Jurnal Semarak, Vol.4,No.2,Juni 2021, Hal (8-30)

@ Prodi Manajemen Fakultas Ekonomi Universitas Pamulang

perusahaan. Artinya hutang yang dimiliki perusahaan dibandingkan dengan asetnya. Secara garis besarr rasio solvabilitas digunakan untuk mengukur kemampuan perusahaan dalam memenuhi kewajiban jangka pendek dan jangka Panjang pada saat perusahaan likuidisi.

Faktor lain yang mempengaruhi nilai perusahan adalah tingkat aktivitas. Rasio aktivitas dapat digunakan untuk mengukur efektivitas penggunaan sumber daya perusahaan. Tingkat aktivitas juga dapat digunakan untuk menilai kemampuan perusahaan dalam melakukan aktivitas sehari-hari. Kegiatan evaluasi menunjukkan apakah perushaan lebih efektif dalam pengelolaan asetnya dan sebaliknya.

Rasio profitabilitas juga dapat mempengaruhi nilai suatu perusahaan, karena rasio ini dapat menilai kemampuan perusahan dalam menghasilkan keuntungan. Selain itu, indikator ini juga dapat mengukur efektivitas manajemen perusahaan yang menghasilkan laba besar. Berfokus pada perusahaan dapat membawa keuntungan bagi pemilik dan karyawan, serta dapat meningkatkan kualitas produk dalam melakukan investasi baru.

Rasio Profitabilitas juga dapat mempengaruhi nilai perusahaan karena rasio ini dapat menilai kemampuan perusahaan dalam mencari keuntungan atau laba, selain itu juga rasio ini memberikan ukuran tingkat efektivitas manajemen suatu perusahaan, dengan memperoleh laba yang maksimal yang telah ditargetkan maka perusahaan dapat memberikan kesejahteraan bagi pemilik, karyawan serta dapat meningkatkan mutu produk dan dapat melakukan investasi baru.

Perusahaan industry logam yang terdaftar di Bursa Efek Indonesai menjadi fokus penelitian ini.
Dikarenakan pesatnya perkembangan industry manufaktur Indonesia, maka peneliti memutuskan untuk mempelajari perusahaan manufaktur yang bergerak dibidang logam. Berikut adalah perusahaan di industry logam yang terdaftar di Bursa Efek Indonesia (BEII) tercantum pada tabel 1.1.

Tabel 1.1 menunjukkan bahwa 16

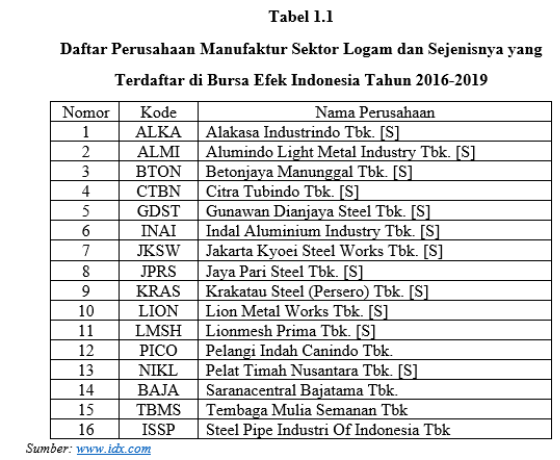

perusahaan di industry logam tercatat di Bursa Efek Indonesia (BEI) antara tahun 2016-2019, tetapi hanya 13 yang bertahan setiap tahun dan merilis laporan keuangan yaitu ALKA, ALMI, BAJA, BTON, CTBN, GDST, INAI, ISSP, LION, LMSH, NIKL, PICO, TBMS.

Seperti diberitakan, industry manufaktur mengalami masalah pelemahan. "Detik.com Kamis 18 Agustus 2016 17:35 WIB, Fenomena yang terjadi di Indonesia dalam pertumbuhan sektor manufaktur riil menurun rata-rata dari $11 \%$ per tahun pada periode 1990-1996, menjadi 4,8\% per tahun pada periode 2001 hingga tahun 2014, hal ini disebabkan karena beberapa faktor yaitu nilai tukar rupiah terhadap dolar AS terdepresiasi sebesar $16 \%$ secara perdagangan tertimbang nominal sejak bulan Desember 2012, Selain itu biaya logistik yang tinggi menjadi penyebab dalam hal infrastruktur dan konektifitas, sehingga rendahnya kinerja manufaktur di tahun 
2000 ini menjadi penurunan pertumbuhan ekonomi di Indonesia".

"Publikasi yang diberitakan

(Katadata.co.id diakses30 Januari 2017) yang berjudul investasi Amerika di Indonesia menurun sejak 2014 yang diberitakan pada Jum'at 20 Januari 2016, diberitakan bahwa: Setelah mencapai puncaknya pada 2013, investasi Amerika Serikat di Insonesia mengalami penurunan periode 20142016, selain itu, investasi asing yang berasal dari negeri Paman Sam pada 2013 mencapai US\$ 2,4 miliar meningkat dua kali lipat dari sebelumnya, Namun setelah itu terus mengalami penurunan meskipun jumlah proyeknya bertambah, Hingga triwulan III 2016". Nilai investasi Amerika di Indonesia hanya mencapai US\$ 430 juta dengan 343 proyek. Ketidak pastian ekonomi global serta turunnya harga minyak hingga di bawah US\$30 per barel membuat investasi Amerika di Tanah air menyusut. Investasi Amerika di Indonesia sepanjang januari September 2016 berada di urutan 10 . Investasi asing terbesar di Indonesia berasal dari negara Singapura dengan nilai US\$7,1 miliar.

Harga saham industri manufaktur sangat fluktuatif dan sulit diprediksi. Selain itu, harga saham industry manufaktur sangat sensitive dengan keadaan perekonomian Indonesia. Beberapa tahun laalu, saat krisis global melanda, harga saham perusahaan menurun selama 5 tahun. penurunan harga saham tersebut disebabkan kenaikan inflasi dan kenaikan suku bunga.

Penurunan nilai perusahaan yang terlihat dari harga saham dipasar modal yang ditandai dengan berkurangnya minat investor pada sector tertentu dan penurunan index produksi akan melemahkan perekonomian. Oleh karena itu, diperlukan peningkatan kinerja perusahaan yang tercermin dari kemampuan perusahaan dalam menarik investor dan menghasilkan keuntungan, serta nantinya berdampak pada peningkatan harga saham dan juga berdampak pada peningkatan nilai perusahaan

Mengacu pada uraina diatas maka penulis tertarik menentukan judul "Pengaruh Kinerja Keuangan Perusahaan Dengan Rasio Keuangan Terhadap Nilai Perusahaan".

\subsection{Perumusan Masalah}

Perumusan masalah penelitian sebagai berikut:

1. Apakah kinerja keuangan dengan rasio likuiditas, rasio solvabilitas, rasio aktivitas, rasio profitabilitas berpengaruh terhadap nilai perusahaan?

2. Apakah kinerja keuangan dengan rasio likuiditas berpengaruh terhadap nilai perusahaan?

3. Apakah kinerja keuangan dengan rasio solvabilitas berpengaruh terhadap nilai perusahaan?

4. Apakah kinerja keuangan dengan rasio aktivitas berpengaruh terhadap nilai perusahaan?

5. Apakah kinerja keuangan dengan rasio profitabilitas berpengaruh terhadap nilai perusahaan?

\subsection{Tujuan Penelitian}

Tujuan penelitian sebagai berikut:

1. Untuk mengetahui dan memberikan bukti empiris kinerja keuangan dengan rasio likuiditas, rasio solvabilitas, rasio aktivitas, rasio profitabilitas berpengaruh terhadap nilai perusahaan.

2. Untuk mengetahui dan memberikan bukti empiris kinerja keuangan dengan rasio likuiditas berpengaruh terhadap nilai perusahaan.

3. Untuk mengetahui dan memberikan bukti empiris kinerja keuangan dengan rasio 
JRNAL ПMПAH

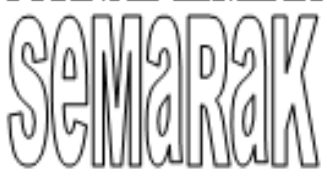

P-ISSN 2615-6849, E-ISSN 2622-3686

Jurnal Semarak,Vol.4,No.2,Juni 2021, Hal (8-30)

@ Prodi Manajemen Fakultas Ekonomi Universitas Pamulang

solvabilitas berpengaruh terhadap nilai perusahaan.

4. Untuk mengetahui dan memberikan bukti empiris kinerja keuangan dengan rasio aktivitas berpengaruh terhadap nilai perusahaan.

5. Untuk mengetahui dan memberikan bukti empiris kinerja keuangan dengan rasio profitabilitas berpengaruh terhadap nilai perusahaan.

\section{TINJAUAN PUSTAKA}

\subsection{Nilai Perusahaan}

"Noerirawan (2012) Nilai Perusahaan adalah kondisi yang telah dicapai oleh suatu perusahaan sebagai gambaran dari kepercayaan masyarakat terhadap perusahaan setelah melalui suatu proses kegiatan selama beberapa tahun, yaitu sejak perusahaan tersebut didirikan sampai dengan saat ini".

"Harmono (2009:233), Nilai Perusahaan adalah kinerja perusahaan yang dicerminkan oleh harga saham yang dibentuk oleh permintaan dan penawaran pasar modal yang merefleksikan penilaian masyarakat terhadap kinerja perusahaan".

"Brigham dan Erdhadt (2005: 518) Nilai Perusahaan adalah nilai sekarang (present value) dari free cash flow di masa mendatang pada tingkat diskonto sesuai rata-rata tertimbang biaya modal". "Free cash flow adalah cash flow yang tersedia bagi investor (kreditur dan pemilik) setelah memperhitungkan seluruh pengeluaran untuk operasional perusahaan dan pengeluaran untuk investasi serta aset lancar bersih".

Penulis menyimpulkan bahwa nilai perusahaan merupakan persepsi investor terhadap perusahaan, dan biasanya berkaitan dengan harga saham. Nilai perusahaan yang dibentuk oleh indikator pasar saham sangat dipengaruhi oleh peluang investasi.

\subsection{Kinerja Keuangan}

Kinerja keuangan merupakan suatu usaha formal yang dilaksanakan perusahaan untuk mengevaluasi efisien dan efektivitas dari kegiatan bisnis yang sudah dilaksanakan pada periode waktu tertentu. Sucipto (2003) pengertian kinerja keuangan adalah penentuan ukuran-ukuran tertentu yang dapat mengukur keberhasilan suatu organisasi atau perusahaan dalam menghasilkan laba. Sedangkan menurut IAI (2007) Kinerja Keuangan adalah kemampuan perusahaan dalam mengelola dan mengendalikan sumberdaya yang dimilikinya. Penulis menyimpulkan berdasarkan pengertian diatas bahwa kinerja keuangan merupakan pekerjaan formal perusahaan dan dapat mengukur keberhasilan perusahaan dalam menghasilkan laba, sehingga dapat melihat prospek, pertumbuhan, dan potensi perusahaan itu sendiri, dan yakin akan berkembang. Gunakanlah sumber daya yang benar. Suatu perusahaan dapat dikatakan berhasil jika memenuhi standar dan tujuan yang sudah ditetapkan.

\subsection{Analisis Rasio Keuangan}

Alat untuk menganalisa laporan keuangan dalam menilai kondisi keuangan perusahaan dapat menggunakan analisis rasio keuangan.

"Kasmir (2016:104) rasio keuangan adalah kegiatan membandingkan angka-angka yang ada dalam laporan keuangan dengan cara membagi satu angka dengan angka lainnya". Menurut Hery (2015:162) "rasio keuangan adalah alat utama untuk melakukan analisis keuangan dan memiliki beberapa kegunaan". Selain itu, menurut Harahap (2015:297) "rasio keuangan adalah angka yang diperoleh dari hasil perbandingan dari satu pos laporan keuangan dengan pos 
lainnya yang mempunyai hubungan yang relevan dan signifikan”.

Penulis menyimpulkan berdasarkan pengertian diatas bahwa analisis rasio keuangan adalah suatu analisis yang menggambarkan hubungan dua atau lebih data keuangan antara yang satu dan yang lainnya. Analisis rasio keuangan berguna dalam menentukan kesehatan keuangan suatu perusahaan baik saat sekarang maupun masa datang. Dengan rasio keuangan kondisi keuangan dan kinerja perusahaan untuk suatu periode tertentu dapat diungkapan serta diketahui kekuatan dan kelemahan perusahaan pada bidang keuangan.

\subsection{Rasio Likuiditas}

"Rasio Likuiditas menurut Kasmir (2017:110) merupakan rasio yang menggambarkan kemampuan perusahaan dalam mencukupi hutang jangka pendek, selain itu fungsi lain rasio likuiditas adalah untuk menunjukkan atau mengukur kemampuan perusahaan dalam memenuhi kewajibannya yang jatuh tempo, baik kewajiban pada pihak perusahaan, dengan kata lain rasio likuiditas untuk mengetahui kemampuan perusahaan dalam membiaya dan memenuhi kewajiban atau utang pada saat ditagih".

Rasio likuiditas atau yang sering dikenal dengan rasio madal kerja merupakan salah satu indikator utama yang digunakan untuk mengukur likuiditas suatu perusahaan. Caranya dengan membandingkan komponenkomponen dalam laporan posisi keuangan yaitu total asset lancer dan total liabilitas atau utang jangka pendek. Penilaian dapat dilakukan dalam beberapa periode agar likuiditas perusahaan dapat berkembang dari waktu kewaktu.

Jenis rasio likuiditas diantaranya: rasio lancar (Current ratio), Rasio sangat lancar (Quick ratio atau acid test ratio), Rasio kas (Cash Ratio), Rasio perputaran kas, inventory to net working capital. Pada penelitian ini menggunakan Rasio cepat (Quick Ratio) menunjukkan kemampuan perusahaan dalam memenuhi atau membayar kewajiban atau utang lancar atau utang jangka pendek, dengan aktiva lancar tanpa memperhitungkan sediaan (inventory) artinya nilai sediaan diabaikan dengan cara dikurangi daari nilai total aktiva lancar hal in dilakukan karena sediaan dianggap memerlukan waktu relative lebih lama untuk diuangkan, apabila perusahaan membutuhkan dana cepat untuk membayar kewajibannya dibandigkan dengan aktiva lancar lainnya. Jika hasil rasio cepat (quick ratio) melebihi 1,0 maka kemampuan perusahaan untuk melunasi utang jangka pendek dinilai baik. Sebaliknya jika melebihi 3,0 maka maka kemampuan perusahaan dinilai kurang produktif. Hal ini karena aktiva lancar tidak didistribusikan secara maksimal dalam bentuk investasi lain.

\subsection{Rasio Solvabilitas}

"Kasmir (2017:151) Rasio solvabilitas atau leverage merupakan rasio yang digunakan untuk mengukur sejauh mana aktiva perusahaan dibiayai dengan utang, Artinya berapa besar beban utang yang ditanggung perusahaan dibandingkan dengan aktivanya dalam arti luas dikatakan bahwa rasio solvabilitas digunakan untuk mengukur kemampuan perusahaan untuk membayar seluruh kewajibannya, baik jangka pendek maupun jangka Panjang apabila perusahaan dibubarkan atau dilikuidasi, perusahaan dikatakan solvabel apabila perusahaan tersebut mempunyai aktiva atau kekayaan yang cukup untuk membayar semua hutangnya". Penggunaan utang terlalu besar yang melebihi batas tertentu akan 
JRNAL ПММАH

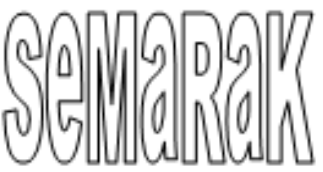

mempertinggi

kemungkinan

perusahaan tidak dapat mengembalikan utang karena harus membayar angsuran dan bunga tetap.

Hal ini menunjukkan bahwa semakin banyak hutang yang dimiliki semakin besar kemungkinan bisnis akan mengalami kesulitan keuangan. Risiko kerugian ini meningkat jika hasil perhitungan menunjukkan bahwa perusahaan memiliki rasio solvabilitas yang tinggi. Sebaliknya apabila perusahaan memiliki rasio solvabilitas lebih rendah tentu mempunyai risiko kerugian lebih kecil pula, terutama pada saat perekonomian menurun. Dampak ini juga mengakibatkan rendahnya tingkat hasil pengembalian (return) pada saat perekonomian tinggi. Dalam rasio solvabilitas, perusahaan sering kali menggunakan beberapa rasio, seperti; perbandingan rasio antara total liabilitas dengan total asset (debt to asset ratio), rasio yang digunakan untuk menilai utang dengan ekuitas (debt to equity ratio), rasio antara utang jangka Panjang dengan modal sendiri (long term debt to equity ratio), tangible assets debt coverage, current liabilities to net worth, rasio yang digunakan untuk membandingkan antara laba sebelum Bungan dan pajak dibandingkan dengan biaya bunga yang dikeluarkan (times interest earned), fixed charge coverage.

Debt to equity ratio digunakan dalam penelitian ini yaitu menilai utang dengan ekuitas. Rasio ini dihitung dengan membandingkan semua kewajiban (termasuk kewajiban lancar) dengan total modal. Rasio ini digunakan untuk menentukan jumlah dana yang akan diberikan peminjam atau kreditor kepada pemilik bisnis. Dengan kata lain, rasio ini digunakan untuk menentukan modal dari setiap rupiah yang digunakan sebagai jaminan hutang. Seluruh hutang perusahaan akan dibandingkan dengan jumlah ekuitas perusahaan untuk mengukur bagaimana kemampuan suatu bisnis membayar utang dan dipengaruhi dengan ekuitas.

\subsection{Rasio Aktivitas}

"Rasio Aktivitas (Activity Ratio) menurut Kasmir (2017: 172) merupakan rasio yang digunakan untuk mengukur efektifitas perusahaan dalam menggunakan aktiva yang dimilikinya, selain itu, rasio ini juga digunakan untuk mengukur tingkat efisiensi atau efektifitas pemanfaatan sumber daya perusahaan". Misalnya, peningkatan efisiensi telah dicapai dibidang penjualan, penyiapan dan penagihan debitur, sedangkan dibidang lain dioptimalkan. Indikator aktivitas juga digunakan untuk menilai kemampuan perusahaan dalam melakukan aktivitas sehari-hari. Dilihat dari hasil statistik aktivitas menunjukkan apakah perusahaan lebih efektif dalam manajemen asset, dan sebaliknya.

Rasio aktivitas menurut Fahmi (2012) adalah rasio yang menggambarkan sejauh mana suatu perusahaan mempergunakan sumber daya dimilikinya guna menunjang aktifitas perusahaan. Rasio ini menunjukkan semakin besar perputaran aktiva maka semakin efektif perusahaan mengelola aktivanya dalam menghasilkan pendapatab. "Aktiva yang rendah pada tingkat penjualan tertentu akan mengakibatkan semakin besarnya dana kelebihan yang tertanam pada aktiva tersebut, dana kelebihan tersebut akan lebih baik bila ditanamkan pada aktiva lain yang lebih produktif (Sawir, 2009)".

Penggunaan rasio aktivitas adalah dengan cara membandingkan antara tingkat penjualan dengan investasi dalam aktiva untuk satu periode. Artinya diharapkan adanya keseimbangan seperti yang diinginkan antara penjualan 
dengan aktiva misal aktiva lancar dan aktiva tetap lainnya. Tujuan utama rasio ini adalah kemampuan manajemen dalam menggunakan dan mengoptimalkan aktiva yang dimiliki.

\subsection{Rasio Profitabilitas}

"Rasio profitabilitas menurut Kasmir (2017:196) merupakan rasio untuk menilai kemampuan perusahaan dalam mencari keuntungan rasio ini juga memberikan ukuran tingkat efektivitas manajemen suatu perusahaan". Ini dapat dilihat dari keuntungan yang didapatkan dari penjualan dan pendapatan investasi. Intinya adalah penggunaan rasio ini menunjukkan efisiensi perusahaan.

"Rasio aktivitas menurut Fahmi (2012) adalah rasio yang menggambarkan sejauh mana suatu perusahaan mempergunakan sumber daya yang dimilikinya guna menunjang aktifitas perusahaan, rasio ini menunjukkan semakin besar perputaran aktiva maka semakin efektif perusahaan mengelola aktivanya dalam menghasilkan penjualan”. "Aktiva yang rendah pada tingkat penjualan tertentu akan mengakibatkan semakin besarnya dana kelebihan yang tertanam pada aktiva tersebut, Dana kelebihan tersebut akan lebih baik bila ditanamkan pada aktiva lain yang lebih produktif (Sawir, 2009)".

Indikator profitabilitas daapt digunakan dengan membandingkan berbagai komponen laporan keuangan, terutama neraca dan laba rugi. Pengukuran dapat dilakukan dalam siklus bisnis yang berbeda untuk mengamati perkembangan bisnis (penurunan atau peningkatan) selama periode waktu tertentu dan menentukan alasan perubahan tersebut.

Penelitian ini menggunakan ROEreturn on equity yaitu pengukuran rasio laba bersih setelah pajak terhadap ekuitas. Rasio ini menunjukkan ekuitas yang efektif. Semakin tinggi rasionya, semkin baik. Artinya posisi pemilik perusahaan akan semakin meningkat, begitu pula sebaliknya.

\subsection{Kerangka Pemikiran}

"Sugiyono (2017:60) kerangka berpikir yang baik akan menjelaskan secara teoritis pertautan antar variabel yang akan diteliti". Berikut adalah kerangka berpikir pada penelitian ini:

\section{METODOLOGI PENELITIAN}

\subsection{Rancangan Penelitian}

"Mengacu pada penelitian Alfredo Mahendra DJ, Luh Gede Sri Artini dan AA Gede Suarjaya (2012) yang menganalisis pengaruh kinerja keuangan terhadap nilai perusahaan pada perusahaan manufaktur di bursa efek Indonesia dan metode yang digunakan adalah data kuantitatif dengan data sekunder dengan pendekatan penelitian deskriptif".

\subsection{Variabel dan pengukuran \\ 3.2.1 Variabel}

Variabel penelitian terdiri dari:

1. Variabel Bebas (Independent Variable)

Variabel bebas adalah variabel yang menjadi penyebab timbulnya variabel lainnya (dependen) yaitu likuiditas, solvabilitas, aktivitas dan profitabilitas.

\section{A. Likuiditas}

"Hani (2015:121) berpendapat bahwa likuiditas adalah kemampuan perusahaan untuk memenuhi semua kewajiban keuangan yang akan jatuh tempo". Rasio yang paling umum menjelaskan likuiditas yaitu Current Ratio (CR), Indikator pengukuran menggunakan rumus berikut:

Quick Ratio $=\frac{\text { Current Assets-Inventory }}{\text { Current Liabilities }}$

B. Solvabilitas

"Kasmir (2017:151), rasio solvabilitas atau rasio leverage merupakan ukuran penting dari seberapa asset suatu perusahaan 
JRNAL ПMПAH

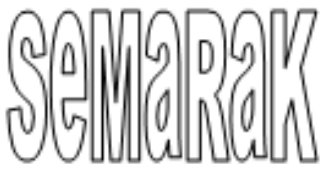

P-ISSN 2615-6849, E-ISSN 2622-3686

Jurnal Semarak,Vol.4,No.2,Juni 2021, Hal (8-30)

@ Prodi Manajemen Fakultas Ekonomi Universitas Pamulang

dibiayai oleh kewajiabannya". Indikator pengukuran menggunakan rumus berikut:

Debt to equity ratio $=\frac{\text { Total utang }(\text { Debt })}{\text { Ekuitas }(\text { Equity })}$

C. Aktivitas

"Kasmir (2017:172) Rasio Aktivitas merupakan rasio yang digunakan untuk mengukur efektifitas perusahaan dalam menggunakan aktiva yang dimilikinya". Tujuan utama dari rasio ini yaitu kemampuan manajemen untuk memanfaatkan dan mengoptimalkan kepemilikan asset. Indikator pengukuran menggunakan rumus berikut:

Inventory Turn Over $=\frac{\text { Penjualan }(\text { sales })}{\text { Sediaan }(\text { Inventory })}$

D. Profitabiltas

"Rasio profitabilitas menurut Kasmir (2017:196) adalah rasio mengevaluasi kemampuan perusahaan dalam menghasilkan laba dan mengukur efisiensi manajemen perusahaan". Dengan rumus yang digunakan adalah:

2. Variabel terikat (Dependent Variable)

Variabel yang dijelaskan atau dipengaruhi yang menjadi akibat karena adanya variabel bebas atau variable independent yaitu capital

Return on Equity $/$ ROE $=\frac{\text { Earning After Interest and Tax }(\text { EAIT })}{\text { Ekuitas }(\text { Equity })}$

expenditure.

A. Nilai Perusahaan

Variabel dependen dalam penelitian ini Penelitian untuk variable dependen yaitu menggunakan nilai perusahaan dengan menggunakan pengukuruan sebagai berikut:

\subsection{Populasi dan Sampel Penelitian}

Populasi merupakan keseluruhan subyek penelitian. Populasi yang digunakan pada penelitian ini yaitu seluruh perusahaan yang sudah terdaftar di BEI dalam sub sektor logam dan sejenisnya, yang berjumlah 16 perusahaan.

Sampel yang diambil dari populasi tersebut yaitu 13 perusahaan. Dengan menggunakan teknik purposive sampling menurut "Prof. Dr. Sugiyono (2017:85) adalah teknik untuk menentukan sampel penelitian dengan beberapa pertimbangan tertentu yang

Price to Eaening Ratio $=\frac{\text { harga saham per lembar }(\text { closing price })}{\text { laba per saham }(\text { Earing per share })}$

bertujuan agar data yang diperoleh nantinya bisa lebih representative". Sampel penelitian yang dipilih berdasarkan pada kriteria berikut:

1. Perusahaan manufaktur pada Subsektor Logam dan Sejenisnya yang terdaftar di Bursa Efek Indonesia tahun 2016-2019.

2. Perusahaan manufaktur pada Subsektor Logam dan Sejenisnya yang terdaftar di BEI dan mempublikasikan laporan tahunannya untuk periode tahun 2016-2019 secara berturut-turut.

3. Perusahaan manufaktur pada Subsektor Logam dan Sejenisnya yang menggunakan mata uang rupiah pada periode tahun 2016-2019.

4. Laporan keuangan dipublikasikan dalam mata uang rupiah (Rp) sebagai mata uang pelaporan.

\subsection{Metode Pengumpulan Data}

Metode pengumpulan data yang digunakan yaitu metode pengumpulan dokumen yang bertujuan untuk memeriksa atau mengumpulkan catatan dan dokumen yang berhubungan dengan masalah penelitian dan survei Pustaka, serta mengunduh data laporan keuangan tahunan perusahaan yang terdaftar pada BEI sub logam dan sejenisnya dan dapat diunduh dari link www.idx.co.id..

\subsection{Metode Analisis Data}


JRNAL ПММАH

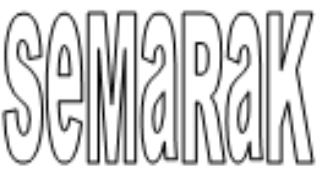

Metode analisis adalah kuantitatif yaitu angka-angka yang dapat dihitung dan diukur. Pengolahan data pada metode ini melalui beberapa tahap.

\subsubsection{Uji Statistik Deskriptif}

Tujuan uji statistik deskriptif adalah untuk menjelaskan secara statistik variabel-variabel yang diteliti. Statistik deskriptif menjelaskan bagaimana data dikategorikan menjadi sebuah kelompok-kelompok data yang lebih mudah dianalisis atau dibaca oleh pengguna informasi (Ghozali, 2018).

\subsubsection{Uji Asumsi Klasik}

Uji asumsi klasik bertujuan untuk menentukan model regresi apakah model regresi layak untuk diteliti atau tidak. Pengujian asumsi klasik meliputi: uji normalitas, uji multikolinearitas, uji autokorelasi dan uji heteroskedastisitas.

\subsubsection{Analisis Data Panel}

Data yang digunakan dalam penelitian ini merupakan kombinasi dari data times series dan cross section. Estimasi yang dilakukan dengan menyatukan kedua data tersebut yang disebut dengan data pooling atau panel data dengan pengolahan data menggunakan software Eviews versi 9 for windows untuk menjelaskan hubungan antara variabel independent.

Ghozali (2013:231) "data panel (pool) yakni data yang merupakan gabungan antara runtun waktu (times series) dengan saksi silang (cross section)". Oleh karena itu, data panel memiliki kombinasi dua karakteristik. Dengan kata lain, ini adalah data yang terdiri dari banyak objek mencakup beberapa waktu. Model estimasi model regresi dengan data panel dapat diselesaikan dengan menggunakan tiga metode tersebut:

\section{Common Effect}

P-ISSN 2615-6849, E-ISSN 2622-3686 
JRNAL ПММАH

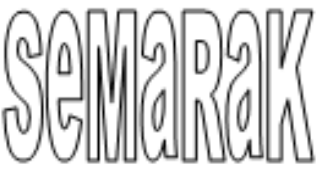

untuk pengujian tersebut. Asumsinya adalah:

$\mathrm{H}_{0}: \quad \beta 1=0$ \{maka digunakan model common effect $\}$

$\mathrm{H}_{1}: \beta 1 \neq 0$ \{maka digunakan model fixed effect $\}$

Kesimpulan saat selesai melakukan chow test dengan eviews adalah:

1. Hasil redundant fixed effect atau likelihood ratio untuk model ini memiliki nilai probabilitas $\mathrm{F}<$ dari alpha (0.05), sehingga $\mathrm{H} 0$ ditolak dan H1 diterima, model yang sesuai dari hasil ini yaitu fixed effect.

2. Hasisl redundant fixed effect atau likelihood ratio untuk model ini memiliki nilai probabilitas $\mathrm{F}>$ dari alpha (0.05), sehingga $\mathrm{H} 0$ diterima dan H1 ditolak, model yang sesuai dari hasil ini yaitu common effect.

\section{Uji Hausman}

Pengujian ini dilakukan untuk menguji apakah data yang dianalisis memiliki pengaruh FEM atau REM tes dilakukan dengan menggunakan program e-views 9. Penerapan uji data hausman juga dapat ditelusuri kembali ke REM dan FEM melalui asumsi berikut:

$\mathrm{H}_{0}: \quad \beta 1=0$ \{maka digunakan model random effect $\}$

$\mathrm{H}_{1}: \quad \beta 1 \neq 0$ \{maka digunakan model fixed effect $\}$

Kesimpulan saat selesai melakukan hausman test dengan eviews adalah:

1) Jika Hausman Test menerima $\mathrm{H} 1$ atau p-value <0.05 maka metode yang dipilih adalah fixed effect.

2) Jika Hausman Test meneriam $\mathrm{H} 0$ atau p-value $>0.05$ maka metode dipilih adalah random effect.

\section{Laglanger Multiplier}

Uji Lagrange Multiplier tujuan utamanya adalah untuk menentukan apakah data fit dengan menggunakan model common effect atau dengan model random effect:
$\mathrm{H}_{0}: \beta 1=0$ \{maka digunakan model common effect $\}$

$\mathrm{H}_{1}: \quad \beta 1 \neq 0 \quad$ maka digunakan model random effect $\}$

Kriteria uji nilai p-value:

1. Jika Crossection-Breus Pagan < 0.05 (alpha:5\%) maka dapat disimpulkan bahwa data fit dengan model random effect.

2. Jika Crossection-Breus Pagan > 0.05 (alpha:5\%) maka dapat disimpulkan bahwa data fit dengan model common effect.

\subsubsection{Analisa Regresi Berganda}

Regresi linear berganda digunakan sebagai alat analisis pengolahan data karena penelitian ini menggunakan tiga variable bebas terhadap satu variable terikat. "Analisis regresi sederhana digunakan untuk mengetahui Rasio Likuiditas (X1), Rasio Solvabilitas (X2), Rasio Aktivitas (X3), Rasio Profitabilitas terhadap Nilai Perusahaan (Y)". Rumus yang digunakan dalam persamaan regresi linear sederhana adalah sebagai berikut:

\subsubsection{Uji Hipotesis}

1. Uji t

"Ghozali (2018:98-99) uji ini bertujuan untuk menunjukkan seberapa jauh pengaruh satu variabel independen secara individu dalam menerangkan variasi variabel dependen". Ketentuan untuk penerimaan atau penolakan hipotesis antara lain:

$\mathrm{H}_{0}$ : Secara parsial variabel independen tidak berpengaruh terhadap variabel dependen.

$\mathrm{H}_{1}$ : Secara parsial variabel independen berpengaruh terhadap variabel dependen.

Dengan kriteria:

1) $t_{\text {hit }}>t_{\text {tabel }}$ atau nilai prob. t-statistik $<$ taraf signifikansi : maka $\mathrm{H}_{0}$ ditolak $\mathrm{H}_{1}$ diterima, yang berarti bahwa variabel bebas $(\mathrm{X} 1, \mathrm{X} 2)$ secara 
JRNAL ПММАH

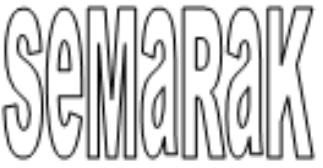

parsial berpengaruh terhadap variabel terikat $(\mathrm{Y})$.

2) $t_{\text {hit }}<t_{\text {tabel }}$ atau nilai prob. t-statistik $>$ taraf signifikasi : maka $\mathrm{H}_{0}$ diterima $\mathrm{H}_{1}$ ditolak, yang berarti bahwa variabel bebas $(\mathrm{X} 1, \mathrm{X} 2)$ secara parsial tidak berpengaruh terhadap variabel terikat $(\mathrm{Y})$.

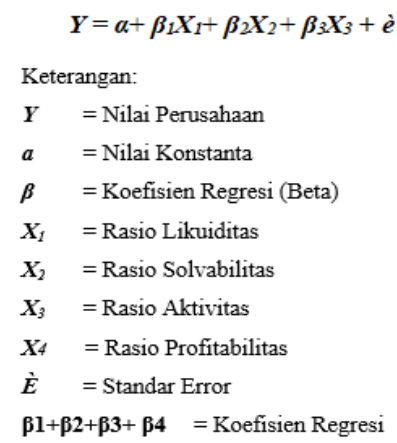

2. Uji Goodness of Fit (Uji F dan $\mathbf{R}^{2}$ )

Untuk mengukur kesesuaian sampel antara harapan dengan aktual digunakan:

A. Uji F (Uji Simultan)

"Ghozali (2018:98) pengujian ini dimaksudkan untuk menunjukkan apakah semua variable independent dalam model mempengaruhi variable dependen". Test ini dapat dikonfirmasi dengan nilai F-test. Nilai $F$ untuk penelitian ini menggunakan taraf signifikansi 0.05 dan kriteria pengujian digunakan adalah:

1) Jika nilai signifikansi $F<0,05$ atau $F_{\text {hitung }}>F_{\text {tabel }}$ menunjukan bahwa uji model ini layak untuk digunakan pada penelitian.

2) Jika nilai signifikansi $F>0,05$ atau $\mathrm{F}_{\text {hitung }}<\mathrm{F}_{\text {tabel }}$ menunjukan bahwa uji model ini tidak layak untuk digunakan pada penelitian

B. Koefisien Determinasi $\left(\mathrm{R}^{2}\right)$

"Ghozali (2018), koefisien determinasi $\left(\mathrm{R}^{2}\right)$ digunakan untuk mengukur sejauh mana kemampuan model dalam menerangkan variasi variabel dependen". Uji $\mathrm{R}^{2}$ dilakukan untuk mengetahui besarnya kemampuan vaiabel independen dalam menerangkan variasi variabel dependen dan nilai $\mathrm{R}^{2}$ adalah antara nol (0) dan satu (1). Semakin kecil nilai koefisien determinasi $\left(R^{2}\right)$, maka semakin terbatas kemampuan variabel-variabel independen dalam menjelaskan variabel dependennya. "Jika nilai $\mathrm{R}^{2}$ yang mendekati satu (1) berarti variabel-variabel independen memberikan hampir semua informasi yang dibutuhkan untuk memprediksi perubahan variabel dependen (Ghozali, 2018)". Kerugian mendasar penggunaan koefisien determinasi adalah jumlah variable dependen cenderung meningkat. Oleh karena itu peneliti menggunakan nilai Adjusted $R^{2}$ sebagai alat uji. Hal ini karena variable independent yang ditambahkan ke model nilainya dapat meningkat atau menurun. Nilai Adjusted $R^{2}$ yang disesuaikan digunakan karena penelitian tersebut mengandung tiga atau lebih variable independent.

IV. ANALISA DAN PEMBAHASAN

4.1 Gambaran Umum Objek Penelitian

Sumber penelitian ini berasal dari www.idx.com dan www.idnfinancials.com dengan pengambilan data laporan keuangan di beberapa perusahaan subsektor logam dan sejenisnya di BEI dengan 4 tahun pengamatan antara tahun 2016 hingga 2019.

Purposive sampling adalah metode penentuan sampel yang digunakan pada penelitian ini. Berdasarkan kriteria sampel, dapat diketahui bahwa jumlah perusahaan di Indonesia pada tahun 2016 sampai 2019 yang dapat dijadikan sampel adalah sebagai berikut:

Berikut adalah tabel yang berisi perusahaan yang menjadi objek penelitian yang bergerak dibidang sektor Logam dan sejenisnya: 
JRNAL ПММАH

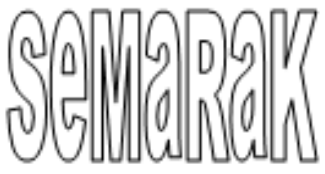

P-ISSN 2615-6849, E-ISSN 2622-3686

Jurnal Semarak,Vol.4,No.2,Juni 2021, Hal (8-30)

@ Prodi Manajemen Fakultas Ekonomi Universitas Pamulang

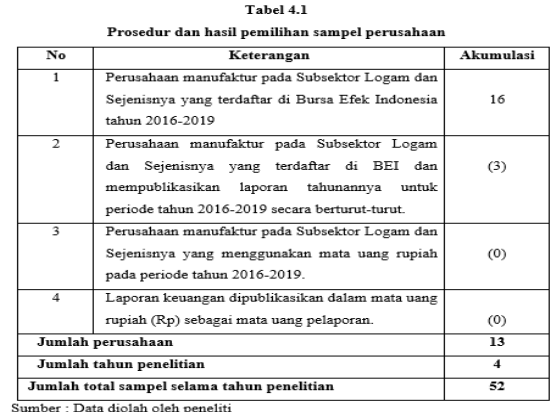

4.2 Analisa Data

\subsubsection{Uji Statistik Deskriptif}

Hasil uji ditampilkan pada tabel

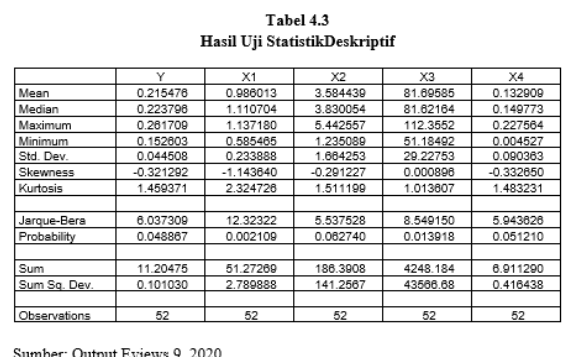

berikut:

Tabel 4.3 menunjukkan bahwa jumlah pengamatan (obs= Observations) pada penelitian ini adalah perusahaan sub sektor property dan real estate yaitu sebanyak 52 yang berasal dari 13 perusahaan dengan periode 2016-2019.

1. Nilai perusahaan pada penelitian ini dengan nilai mean sebesar 0.215476 nilai maximum 0.261709 dan nilai minimum sebesar 0.152603 sandar devisiasi 0.044508 nilai sum 11.20475 dan nilai skewness 0.321292 serta nilai kurtosis 1.459371 . Artinya jika nilai mean lebih besar dari standar deviasi menunjukan sebaran data yang baik dan data bersifat homogen atau seragam.

2. Likuiditas pada penelitian ini memiliki nilai mean $\begin{array}{lll}\text { sebesar } & 0.986013 \quad \text { nilai }\end{array}$ maximum 1.137180 dan nilai minimum sebesar 0.585465 standar deviasi 0.233888 nilai sum 51.27269 dan nilai skewness 1.143640 serta nilai kurtosis 2.324726. Artinya jika nilai mean lebih besar dari standar deviasi menunjukan sebaran data yang baik dan data bersifat homogen atau seragam.

3. Solvabilitas pada penelitian ini nilai mean sebesar 3.584439 nilai maximum 5.442557 dan nilai minimum sebesar 1.235089 standar deviasi 1.664253 nilai sum 186.3908 dan nilai skewness -0.291227 serta nilai kurtosis 1.511199 . Artinya jika nilai mean lebih besar dari standar deviasi menunjukan sebaran data yang baik dan data bersifat homogen atau seragam.

4. Aktivitas pada penelitian ini nilai mean sebesar 81.69585 nilai maximum 112.3552 dan nilai minimum sebesar 51.18492 standar

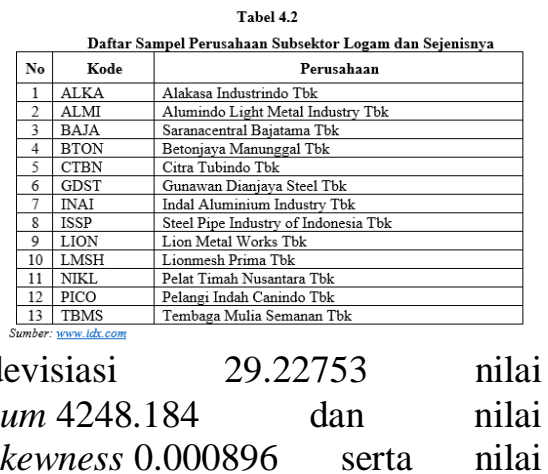
kurtosis 1.013607 . Artinya jika nilai mean lebih besar dari standar deviasi menunjukan sebaran data yang baik dan data bersifat homogen atau seragam.

5. Profitabilitas pada penelitian ini nilai mean sebesar 0.132909 nilai maximum 0.227564 dan nilai minimum sebesar 0.004527 standar devisiasi 0.090363 nilai sum 6.911290 dan nilai skewness- 
JRNAL IMПAH

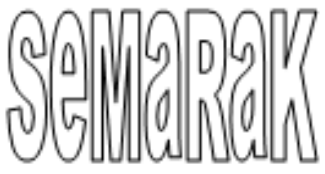

0.332650

serta

nilai

kurtosis 1.483231. Artinya jika nilai mean lebih besar dari standar deviasi menunjukan sebaran data yang baik dan data bersifat homogen atau seragam.

\subsubsection{Hasil Uji Asumsi Klasik}

\subsubsection{Uji Normalitas Data}

Hasil uji ditampilkan pada tabel berikut:

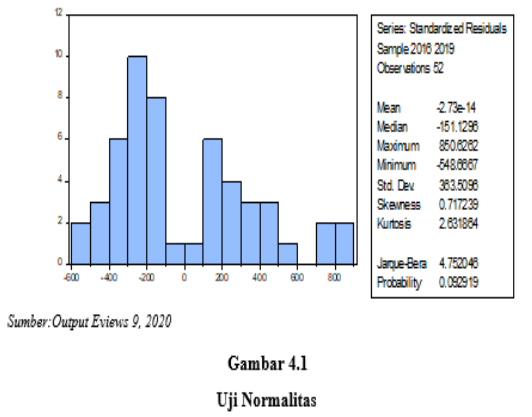

Gambar diatas menunjukkan distribusi normal atau pola grafik yang dapat memenuhi persyaratan normalitas. Hal ini terlihat dari nilai Jarque-Bera sebesar 4,752046, nilai probabilitasnya adalah 0, 092919. Karena nilai ini lebih besar dari $\alpha=0,05(5 \%)(0,092919>$ 0,05), maka dapat disimpulkan bahwa model regresi layak karena alasan berikut: hal ini sesuai dengan asumsi normalitas.

\subsubsection{Uji Multikolinearitas}

Hasil Uji Multikolinearitas data dibawah ini:

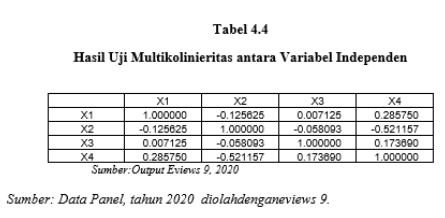

Tabel 4.4 diatas menunjukan nilai untuk setiap variabel independen Penjualan (X1) sebesar 1.000000, Biaya Produksi (X2) sebesar1.000000. Artinya, tidak ditemukan multikolinearitas antar variable
P-ISSN 2615-6849, E-ISSN 2622-3686

Semarak,Vol.4,No.2,Juni 2021, Hal (8-30)

@ Prodi Manajemen Fakultas Ekonomi Universitas Pamulang

\section{Hasil dari pengujian dapat dilihat}

4.2.2.3 Uji Heterokedastisitas pada tabel dibawah ini:

Hasil tabel 4.5 terlihat bahwa nilai

Tabel 4.5

Uji Heterokedastisitas

Heteroskedasticity Test Glejser

\begin{tabular}{llll}
\hline \hline F-statistic & 8.941050 & Prob. $F(2,69)$ & 0.0004 \\
Obs"R-squared & 14.81906 & Prob. Chi-Square(2) & 0.0006
\end{tabular}

\begin{tabular}{llll} 
Obs`R-squared & 14.81908 & Prob. Chi-Square(2) & 0.0006 \\
Scaled explained SS & 14.11844 & Prob. Chi-Square(2) & 0.0009 \\
\hline
\end{tabular}

Sumber: Data Panel, tahun 2020 diolah dengan eviews 9

probabilitas chi-square pada uji heterokedastisitas glestjer sebesar 14,81906 lebih besar dari $\alpha=5 \%$ $(14,81906>0,05)$. Artinya tidak terjadi heterokedastisitas pada model regresi ini.

\subsubsection{Uji Autokorelasi}

Hasil uji ditampilkan pada tabel berikut:

Uji autokorelasi kuadrat-terkecil pada table 4.7 menunjukkan statistic Durbin-Watson 2,004666 antara standar $(1,55-2,45)$. Oleh karena itu, menurut tabel kriteria interpretasi uji Durbin Watson, model regresi ini dengan keterangan tidak ada autokorelasi.

\subsubsection{Pengujian Regresi Data Panel 4.2.3.1 Uji Chow}

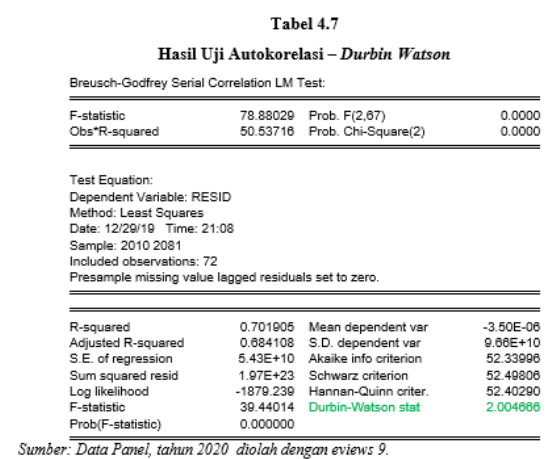


JRNAL ПММАH

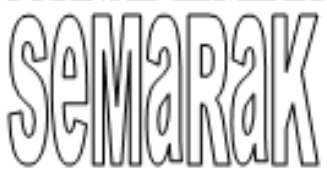

Hasil Uji Chow kinerja keuangan perusasaan dengan Likiditas, Solvabilitas, Aktivitas, Profitabilitas terhadap Nilai Peusahaan:

\begin{tabular}{|c|c|c|c|c|}
\hline \multicolumn{5}{|c|}{$\begin{array}{l}\text { Tabel } 4.8 \\
\text { Uji Chow }\end{array}$} \\
\hline \multicolumn{5}{|c|}{$\begin{array}{l}\text { Redundant Fixed Effects Tests } \\
\text { Equation: Untitled } \\
\text { Test cross-section fixed effects }\end{array}$} \\
\hline Effects Test & & Statistic & d.f. & Prob. \\
\hline $\begin{array}{l}\text { Cross-section F } \\
\text { Cross-section Chi-square }\end{array}$ & & $\begin{array}{l}155.838224 \\
207.839842\end{array}$ & $\begin{array}{r}(12,35) \\
12\end{array}$ & $\begin{array}{l}0.0000 \\
0.0000\end{array}$ \\
\hline \multicolumn{5}{|c|}{$\begin{array}{l}\text { Cross-section fixed effects test equation: } \\
\text { Dependent } V \text { ariable: } Y \\
\text { Method: Panel Least Squares } \\
\text { Date: } 12 / 30 / 20 \text { Time: } 23: 08 \\
\text { Sample: } 20162019 \\
\text { Periods included: } 4 \\
\text { Cross-sections included: } 13 \\
\text { Total panel (balanced) observations: } 52\end{array}$} \\
\hline Variable & Coefficient & Std. Error & t-Statistic & Prob. \\
\hline $\begin{array}{l}\mathrm{C} \\
\times 1 \\
\times 2 \\
\times 3 \\
\times 4\end{array}$ & $\begin{array}{r}233.9882 \\
111.3443 \\
-0.301305 \\
-4.617560 \\
75.15560\end{array}$ & $\begin{array}{l}81.07986 \\
44.38343 \\
0.571525 \\
2.347727 \\
1325.319\end{array}$ & $\begin{array}{r}2.885898 \\
2.508691 \\
-0.527194 \\
-1.966822 \\
0.056708\end{array}$ & $\begin{array}{l}0.0059 \\
0.0156 \\
0.6005 \\
0.0551 \\
0.9550\end{array}$ \\
\hline $\begin{array}{l}\text { R-squared } \\
\text { Adjusted R-squared } \\
\text { S.E. of regression } \\
\text { Sum squared resid } \\
\text { Log likelihood } \\
\text { F-statistic } \\
\text { Prob(F-statistic) }\end{array}$ & $\begin{array}{l}0.197322 \\
0.129009 \\
378.6623 \\
6739100 . \\
-379.8618 \\
2.888490 \\
0.032194\end{array}$ & $\begin{array}{l}\text { Mean depende } \\
\text { S.D. depender } \\
\text { Akaike info crit } \\
\text { Sc hwarz criter } \\
\text { Hannan-Quinn } \\
\text { Durbin-Watsor }\end{array}$ & & $\begin{array}{l}315.8835 \\
405.7374 \\
14.80238 \\
14.99000 \\
14.87431 \\
0.071637\end{array}$ \\
\hline
\end{tabular}

Tabel 4.8 dan tabel 4.9 dapat dilihat hasil Uji Chow pada Penjualan dan Biaya Produksi Terhadap Laba Bersih bahwa nilai probabilitas (prob) cross sections F-statistic adalah $0.0000<$ 0,05 ditentukan sebagai nilai signifikan $\alpha$, maka $\mathrm{H}_{0}$ diterima dan $\mathrm{H}_{1}$ ditolak. Oleh karena itu, kita dapat menyimpulkan bahwa model yang paling tepat adalah dengan menggunakan fixed effect daripada common effect. Langkah selanjutnya dalam menentukan apakah common effect lebih baik daripada random effect memerlukan uji Lagrange Multipleir Test.

\subsubsection{Uji Hausman}

P-ISSN 2615-6849, E-ISSN 2622-3686

@Prodi Manajemen Fakultas Ekonomi Universitas Pamulang

Penelitian ini, pengujian hausman dilakukan dengan memilih REMrandom effect pada opsi panel cross section untuk menguji data panel.

$$
\begin{gathered}
\text { Berdasarkan hasil berupa nilai } \\
\text { Tabel } 4.9 \\
\text { Hasil Uji Hausman }
\end{gathered}
$$

\begin{tabular}{lrrr}
\hline \hline Test Summary & $\begin{array}{r}\text { Chi-sq. } \\
\text { Statistic }\end{array}$ & Chi-Sq. d.f. & Prob. \\
\hline \hline Cross-section random & 1.992648 & 4 & 0.7371 \\
\hline
\end{tabular}

Cross-section random effects test comparisons

\begin{tabular}{crrrr} 
Variable & Fixed & Random & Var(Diff.) & Prob. \\
\hline \hline X1 & 34.452226 & 41.226231 & 69.162082 & 0.4153 \\
X2 & -0.713926 & -0.713766 & 0.000019 & 0.9706 \\
X3 & 0.000769 & -0.200313 & 0.034239 & 0.2772 \\
X4 & 219.186081 & 200.322452 & 428.147542 & 0.3620 \\
\hline \hline
\end{tabular}

Cross-section random effects test equation: Dependent Variable: $Y$

Method: Panel Least Square

Date: $12 / 30 / 20$ Time: $23: 13$ Sample: 20162019

Cross-sections included 13

Total panel (balanced) observations: 52

\begin{tabular}{crrrr}
\multicolumn{1}{l}{ Total panel (balanced) observations: 52} \\
\hline \hline Variable & Coefficient & Std. Error & t-Statistic & Prob. \\
\hline \hline C & 283.4771 & 37.49947 & 7.559498 & 0.0000 \\
X1 & 34.45223 & 29.78739 & 1.156605 & 0.2553 \\
X2 & -0.713926 & 0.100432 & -7.108519 & 0.0000 \\
X3 & 0.000769 & 1.016161 & 0.000757 & 0.9994 \\
X4 & 219.1861 & 243.9560 & 0.898466 & 0.3751 \\
\hline \hline \multicolumn{6}{c}{}
\end{tabular}

Cross-section fixed (dummy variables)

\begin{tabular}{lll}
\hline R-squared & 0.985253 Mean dependent var 315.8835
\end{tabular} Adjusted R-squared $\quad 0.978512$ S.D dependent var $\quad 405.7374$ $\begin{array}{lll}\text { S.E. of regression } & 5947669 \text { Akaike info criterion } & 11.26700\end{array}$ Sum squared resid $\quad 123811.7$ Schwarz criterion $\quad 11.90490$ $\begin{array}{lrll}\text { Log likelihood } & -275.9419 & \text { Hannan-Quinn criter. } & 11.51155 \\ \text { F-statistic } & 146.1486 & \text { Durbin-Watson stat } & 2.082157\end{array}$ Prob(F-statistic) $\quad 0.000000$

Sumber: Output Eviews 9, 2020

probability chi squares sebesar dari taraf signifikansi $(0.7371>0.05)$ maka sebaiknya H0 atau model REMRandom Effect diterima dibandingkan model FEM-Fixed effect.

\subsubsection{Laglanger Multiplier}

Uji laglanger multipler dilakukan untuk menentukan metode terbaik untuk data panel regresi, terlepas dari apakah CEM-common effect atau REMrandom effect. 
JRNAL ПMாAH

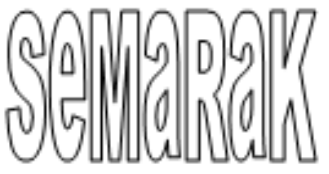

Tabel 4.10

Hasil Laglanger Multipler

Lagrange Multiplier Tests for Random Effects Null hypotheses: No effects Alternative hypotheses: Two-sided (Breusch-Pagan) and one-sided (all others) alternatives

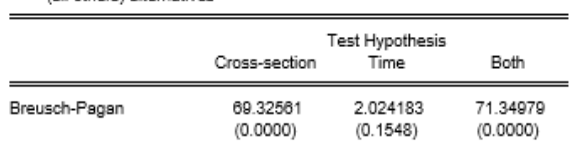

$(0.0000) \quad(0.1548)$

$\begin{array}{llll}\text { Honda } & 8.326200 & -1.422738 & 4.881485 \\ & (0.0000) & (0.8226) & (0.0000)\end{array}$

King-Wu $\quad 8.326200 \quad-1.422738 \quad 2.451055$

$\begin{array}{llll}(0.0000) & (0.8228) & (0.0071)\end{array}$

Standardized Honds $\quad 9.465914 \quad-1.237509 \quad 2.701302$

$\begin{array}{lll}0.0000) & (0.8921) & (0.0035)\end{array}$

Standardized King-Wu $\quad 9.465914 \quad-1.237509 \quad 0.354879$ $\begin{array}{lll}(0.0000) & (0.8921) \quad(0.3613)\end{array}$

$\begin{array}{llll}\text { Gourieroux, et al." } & - & - & \end{array}$

Sumber:Output Eviews 9, 2020

Tabel 4.10 menunjukkan nilai $p$ value 0.0000 yang lebih rendah dari tingkat signifikansi $\quad(0.0000<0.05)$. Maka H0 ditolak atau model REMRandom effect diterima dibandingkan CEM-common effect.

\subsubsection{Hasil Analisa Regresi Berganda}

Hasil uji ditampilkan pada tabel berikut:

Tabel 4.12

Persamaan Model Regresi antara Variabel Likuiditas, Solvabilitas, Aktivitas, Profitabilitas terhadap Nilai Perusahaan

\begin{tabular}{|c|c|c|c|c|}
\hline Variable & Coefficient & Std. Error & $\mathrm{t}$-Statistic & Prob. \\
\hline$c$ & 283.4771 & 37.49947 & 7.559498 & 0.0000 \\
\hline $\mathrm{x} 1$ & 34.45223 & 29.78738 & 1.156005 & 0.2553 \\
\hline$x_{2}$ & -0.713928 & 0.100432 & -7.108519 & 0.0000 \\
\hline & 0.000789 & 1.016161 & 0.000757 & 0.9994 \\
\hline $\mathrm{x}_{4}$ & 219.1861 & 243.9560 & 0.898466 & 0.3751 \\
\hline
\end{tabular}

Tabel 4.12 diatas menunjukkan model regresi yang dapat dibentuk yaitu:

Kesimpulan:

\section{$\mathrm{Y}=1.156605 \mathrm{Xl}-7.108519 \mathrm{X} 2+0.000757 \mathrm{X} 3+0.898466 \mathrm{X} 4$}

1. Konstanta regresi 7.559498 menyatakan bahwa jika variabel bebas Likuiditas, Solvabilitas, Aktivitas, Profitabilitas dianggap nol, maka nilai perusahaan sebesar 7.559498.

2. Konstanta regresi Likuiditas sebesar 1.156605 menyatakan bahwa setiap kenaikan likuiditas sebesar 1 maka akan menaikkan nilai perusahaan sebesar1.156605 .

3. Konstanta regresi Solvabilitas sebesar 7.108519 menyatakan bahwa setiap kenaikan Solvabilitas sebesar 1 maka akan menurunkan nilai perusahaan sebesar -7.108519.

4. Konstanta regresi Aktivitas sebesar 0.000757 menyatakan bahwa setiap kenaikan Aktivitas sebesar 1 maka akan menurunkan nilai perusahaan sebesar0.000757 .

\subsubsection{Hasil Uji Hipotesis}

1. Hasil Uji t

Hasil uji ditampilkan pada tabel berikut:

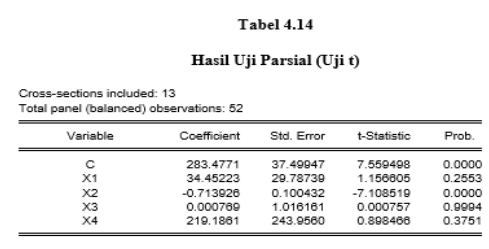

Kesimpulan:

1) Pengaruh Kinerja Keuangan dengan Rasio Likuiditas terhadap Nilai Perusahaan.

Tabel 4.9 diatas, menentukkan besarnya $t$ tabel dicari dengan menggunakan rumus $\mathrm{df}=(\mathrm{n}-\mathrm{k})=52-3=$ 47, maka $\mathrm{t}_{\text {tabel }}(0,05: 57)=2,01174$. Berdasarkan tabel 4.9 maka diperoleh hasil thitung Rasio likuiditas sebesar $1.156605, \mathrm{t}_{\text {tabel }}=2,01174$ sehingga $\mathrm{t}$ hitung $<\mathrm{t}_{\text {tabel }}(1,156605<2,01174)$, hal ini diperkuat dengan nilai probability lebih besar dari signifikansi atau $(0.2553>0,05)$, maka $\mathrm{H}_{1}$ ditolak dan $\mathrm{H}_{0}$ diterima sehingga dapat 
disimpulkan bahwa Rasio Likuiditas tidak berpengaruh terhadap Nilai Perusahaan.

2) Pengaruh Kinerja Keuangan dengan Rasio Solvabilitas terhadap Nilai Perusahaan.

Tabel 4.9 diatas, menentukkan besarnya $t$ tabel dicari dengan menggunakan rumus $\mathrm{df}=(\mathrm{n}-\mathrm{k})=52-3=$ 47, maka $\mathrm{t}_{\text {tabel }}(0,05: 57)=2,01174$. Berdasarkan tabel 4.9 maka diperoleh hasil thitung Rasio Solvabilitas sebesar $1.156605, \mathrm{t}_{\text {tabel }}=2,01174$ sehingga $\mathrm{t}$ hitung $<\mathrm{t}_{\text {tabel }}(-7.108519<2,01174)$, hal ini diperkuat dengan nilai probability lebih besar dari signifikansi atau $(0.000>0,05)$, maka $\mathrm{H}_{0}$ ditolak dan $\mathrm{H}_{1}$ diterima sehingga dapat disimpulkan bahwa Rasio Solvabilitas berpengaruh dan signifikan terhadap Nilai Perusahaan.

3) Pengaruh Kinerja Keuangan dengan Rasio Aktivitas terhadap Nilai Perusahaan.

Tabel 4.9 diatas, menentukkan besarnya $t$ tabel dicari dengan menggunakan rumus $\mathrm{df}=(\mathrm{n}-\mathrm{k})=52-3=$ 47, maka $\mathrm{t}_{\text {tabel }}(0,05: 57)=2,01174$. Berdasarkan tabel 4.9 maka diperoleh hasil thitung Rasio Aktivitas sebesar $0.000757, \mathrm{t}_{\text {tabel }}=2,01174$ sehingga $\mathrm{t}$ hitung $<\mathrm{t}_{\text {tabel }}(0.000757<2,01174)$, hal ini diperkuat dengan nilai probability lebih besar dari signifikansi atau (0.9994 > 0,05), maka $\mathrm{H}_{1}$ ditolak dan $\mathrm{H}_{0}$ diterima sehingga dapat disimpulkan bahwa Rasio Aktivitas tidak berpengaruh dan tidak signifikan terhadap Nilai Perusahaan.

4) Pengaruh Kinerja Keuangan dengan Rasio Profitabilitas terhadap Nilai Perusahaan.

Tabel 4.9 diatas, menentukkan besarnya $t$ tabel dicari dengan menggunakan rumus $\mathrm{df}=(\mathrm{n}-\mathrm{k})=52-3=$ 47, maka $\mathrm{t}_{\text {tabel }}(0,05: 57)=2,01174$. Berdasarkan tabel 4.9 maka diperoleh hasil thitung Profitabilitas sebesar
0.898466, $\mathrm{t}_{\text {tabel }}=2,01174$ sehingga $\mathrm{t}$ hitung $<\mathrm{t}_{\text {tabel }}(0.898466<2,01174)$, hal ini diperkuat dengan nilai probability lebih besar dari signifikansi atau $(0,3751>0,05)$, maka $\mathrm{H}_{1}$ ditolak dan $\mathrm{H}_{0}$ diterima sehingga dapat disimpulkan bahwa Rasio Profitabilitas tidak berpengaruh dan tidak signifikan terhadap Nilai Perusahaan

2. Hasil Uji Goodness of Fit (Uji F dan $\mathbf{R}^{2}$ )

A. Hasil Uji F (Uji Simultan)

Hasil uji ditampilkan pada tabel berikut:

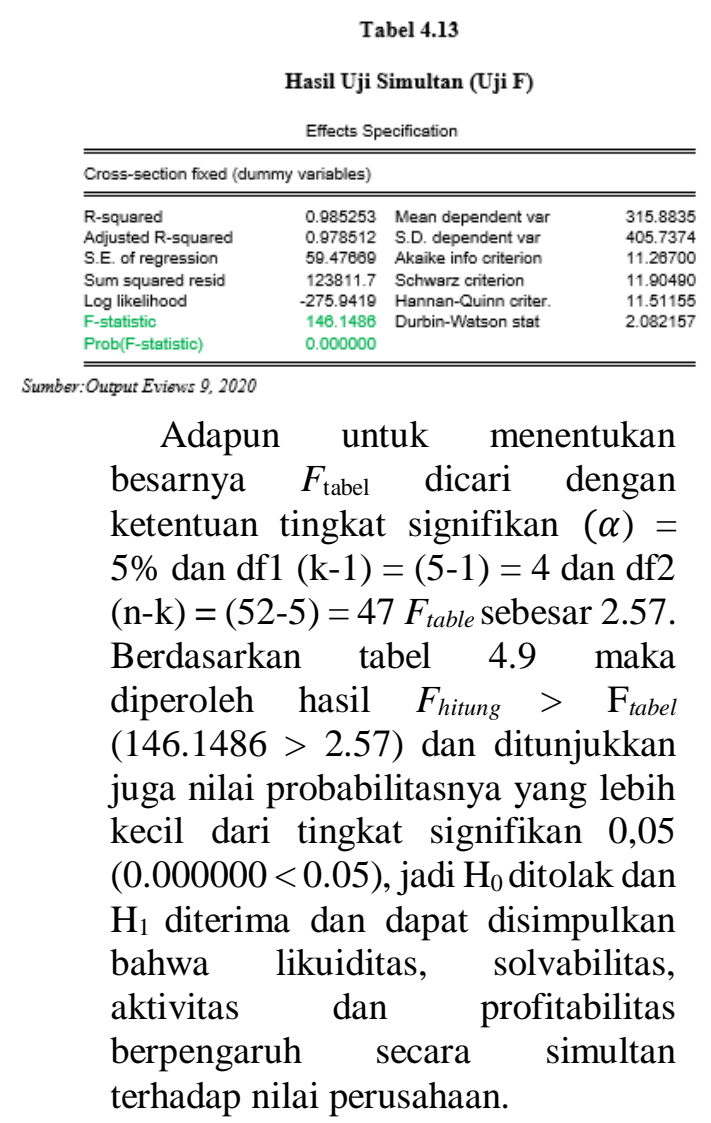

B. Hasil Koefisien Determinasi $\left(\mathrm{R}^{2}\right)$ 
JRNAL ПMПAH

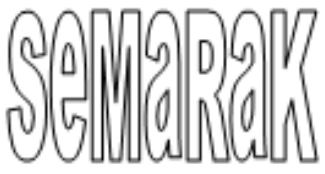
berikut

Hasil uji ditampilkan pada tabel

\begin{tabular}{|c|c|c|c|}
\hline & Koefisi & $\begin{array}{l}\text { Table } 4.11 \\
\text { ien Determinasi } \\
\text { ecification }\end{array}$ & \\
\hline \multicolumn{4}{|c|}{ Cross-section fxed (dummy variables) } \\
\hline R-squared & 0.885253 & Mesn dependent var & $\overline{315.8835}$ \\
\hline Adjusted R-squared & 0.978512 & S.D. dependent var & \\
\hline S.E. of regression & $\begin{array}{l}59.47868 \\
138117\end{array}$ & Aksike info criterion & $\begin{array}{l}11.28700 \\
11.90480\end{array}$ \\
\hline Sum squared resid & $\begin{array}{r}123811.7 \\
-2759419\end{array}$ & $\begin{array}{l}\text { Schwwarz criterion } \\
\text { Hannan-Quinn criter }\end{array}$ & $\begin{array}{l}11.90480 \\
11.51155\end{array}$ \\
\hline $\begin{array}{l}\text { Log gikelinood } \\
\text { F-statistic }\end{array}$ & $\begin{array}{l}-217.84198 \\
146.1488\end{array}$ & Durbin-Watson stat & 2.082157 \\
\hline Prob(F-statistic) & 0.000000 & & \\
\hline
\end{tabular}

Koefisien determinasi penjualan dan biaya produksidapat dillihat pada tabel 4.10 dengan besarnya angka Adjusted R-Square (R2) adalah 0.978512 hal ini menunjukkan bahwa persentase memberikan pengaruh variabel independen terhadap variabel dependen sebesar $, 97,8 \%$ sedangkan sisanya $2,2 \%$ lainnya dipengaruhi oleh faktor lain diluar dari model regresi ini.

\subsection{Pembahasan}

Hasil yang diperoleh dari hasil uji statistik t yang menguji secara parsial pengaruh dari masing-masing variabel independen, dan hasil uji statistik F yang menguji secara simultan pengaruh variabel independen terhadap dependen. Maka hasil tersebut dapat dijelaskan sebagai berikut:

1. Hipotesis pertama $\left(\mathrm{H}_{1}\right)$ diterima. Hasil penelitian yang telah dilakukan diperoleh hasil dengan nilai probabilitasnya yang lebih kecil dari tingkat signifikan 0,05 (0.000000 < 0.05) dapat disimpulkan bahwa likuiditas, solvabilitas, aktivitas dan profitabilitas berpengaruh secara simultan terhadap nilai perusahaan, dengan kinerja keuangan yang efisien dan efektif perusahaan mampu dalam penyiapan pembiayaan atas kewajiban baik jangka pendek dan jangka panjang maka perusahaan tersebut dikatakan likuid, dan kemampuan menyiapkan sumber dana yang selalu diperlukan untuk melakukan ekpansi atau perluasan usaha artinya perusahaan harus sselalu tersedia dana dalam jumlah tetentu sehingga tersedia pada saat dibutuhkan. Penelitian kinerja keuangan dengan rasio aktivitas diketahui bahwa secara keseluruhan perusahaan mampu mengatasi berbagai hal yang berkaitan dengan aktivitas perusahaan terutama pada penjualan yang dimana persediaan selau tersedia digudang sehingga manajemen dapat mengukur kinerja periode saat ini dengan periode sebelumnya yaitu dengan mengukur perputaran modak kerja, perputaran aktiva, sediaan, dan penggunaan seluruh aktiva terhadap penjualan. Hasil penelitian secara simultan untuk kinerja perusahaan dengan Rasio Profitabilitas membuktikan perusahaan mampu memperoleh laba atau keuntungan yang maksimal, dengan memperoleh laba yang maksimal perusahaan dapat memberikan kesejahteraan bagi pemilik perusahaan, karyawan, serta dapat meningkatkan mutu produk dan melakkukan investasi baru. Maka dengan adanya penelitian ini didapat hasil secara simultan antara kinerja keuangan dengan rasio keuangan berpengaruh secara simultan terhadap nilai perusahaan, penelitian ini sejalan dengan penelitian terdahulu Faldy G. Lumentut Marjam Mangantar (2017) Secara simultan rasio likuiditas, profitabilitas, solvabilitas dan aktivitas berpengaruh terhadap nilai perusahaan manufaktur.

2. Hipotesis kedua $\left(\mathrm{H}_{2}\right)$ ditolak. Hasil penelitian yang telah dilakukan, dari persamaan regresi sederhana pada model analisis untuk hipotesis kedua menyatakan bahwa hasil uji $t$ memberikan informasi bahwa 
likuiditas secara parsial tidak berpengaruh dan tidak signifikan terhadap Nilai Perusahaan. Berarti perusahaan tidak mampu memenuhi kewajibannya, semakin tinggi tingkat likuiditas perusahaan, maka semakin tinggi juga kinerja perusahaan tersebut. Selain itu, biasanya perusahaan dengan tingkat likuiditas tinggi akan memiliki kesempatan lebih baik untuk mendapatkan berbagai dukungan dari banyak pihak, mulai dari lembaga keuangan, kreditur, maupun pemasok. Di mana, dengan mempertahankan likuiditasnya, perusahaan bisa mendapatkan kepercayaan dari pihak internal maupun eksternal. Pihak internal yang dimaksud di sini misalnya adalah seorang karyawan, dengan tingkat likuiditas yang baik, perusahaan mampu membayarkan gaji karyawan sesuai tanggal yang ditentukan. Sedangkan, bagi pihak eksternal misalnya supplier, likuiditas ini bisa membuat pihak eksternal lebih percaya dengan perusahaan Bukan hanya bagi supplier, dan dengan mudah mendapatkan pinjaman modal dari bank, investor, maupun pihak lainnya. Penelitian yang dilakukan pada perusahaan pada subsektor logam dan sejenisnya dinyatakan bahwa kinerja keuangan dengan pengukuran Likuiditas tidak berpengaruh terhadap Nilai Perusahaan menandakan likuiditas perusahaan kurang baik dan dalam pemenuhan atas kewajiban lancarnya belum dikatakan baik. Semakin besar perbandingan aktiva lancar dan kewajiban lancar, semakin tinggi kemampuan perusahaan dalam menutupi kewajiban jangka pendeknya. penelitian ini sejalan dengan penelitian terdahulu Faldy G. Lumentut, Marjam Mangantar (2017), hasil penelitian ini menunjukkan bahwa secara parsial likuiditas dan profitabilitas tidak berpengaruh terhadap nilai perusahaan manufaktur. Hal ini sejalan dengan teori sinyal yang menyatakan bahwa jika nilai likuiditas tinggi dan nilai profitabilitas yang tinggi, maka investor atau kreditur akan menerima sinyal positif bahwa perusahaan berada dalam kondisi yang menguntungkan, hal tersebut menjadi daya tarik investor untuk memiliki saham perusahaan. Permintaan saham yang tinggi akan membuat para investor akan menghargai nilai saham lebih besar daripada nilai yang tercatat pada nilai perusahaan, sehingga nilai perusahaan akan menjadi tinggi.

3. Hipotesis ketiga $\left(\mathrm{H}_{3}\right)$ diterima. Hasil penelitian yang telah dilakukan, dari persamaan regresi sederhana pada model analisis untuk hipotesis ketiga menyatakan bahwa hasil uji t (uji parsial) memberikan informasi bahwa kinerja keuangan dengan pengukuran Solvabilitas secara parsial berpengaruh dan signifikan terhadap Nilai Perusahaan. Yang dimana rasio solvabilitas dapat mengukur sejauh mana aktiva perusahaan dibiayai dengan utang. Artinya berapa banyak beban utang yang ditanggung perusahaan dibandingkan dengan asetnya, Oleh karena itu, rasio solvabilitas digunakan untuk mengukur kemampuan perusahaan dalam melunasi seluruh hutang, apabila perusahaan dibubarkan atau dilikuidasi, perusahaan dikatakan solvabel apabila perusahaan tersebut mempunyai aktiva atau kekayaan yang cukup untuk membayar semua hutangnya. Penggunaan utang terlalu besar yang melebihi batas tertentu akan mempertinggi kemungkinan perusahaan tidak dapat mengembalikan kewajibannya dikarenakan harus membayar angsuran dan bunga tetap. Hal ini 
JRNAL ПMПAH

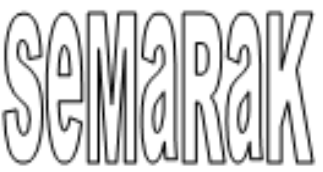

P-ISSN 2615-6849, E-ISSN 2622-3686

Jurnal Semarak, Vol.4,No.2,Juni 2021, Hal (8-30)

@ Prodi Manajemen Fakultas Ekonomi Universitas Pamulang

menunjukkan semakin tinggi utang semakin besar kemungkinan perusahaan mengalami kesulitan finansialnya. Apabila dari hasil perhitungan perusahaan ternyata memiliki rasio solvabilitas yang tinggi, hal ini akan berdampak timbulnya risiko kerugian lebih besar. Sebaliknya apabila perusahaan memiliki rasio solvabilitas lebih rendah tentu mempunyai risiko kerugian lebih kecil pula, terutama pada saat perekonomian menurun. Dampak ini juga mengakibatkan rendahnya tingkat hasil pengembalian (return) pada saat perekonomian tinggi. Dari hasil penelitian kinerja keuangan dengan rasio solvabilitas berpengaruh terhadap nilai perusahaan yana dimana penelitian ini sejalan dengan penelitian terdahulu A.A. Ngr Bgs Aditya Permana, Henny Rahyuda (2019), Solvabilitas dan likuiditas secara parsial berpengaruh negatif terhadap nilai perusahaan. Dan sejalan juga dengan penelitian Faldy G. Lumentut, Marjam Mangantar (2017), hasil solvabilitas dan aktivitas secara parsial berpengaruh terhadap nilai perusahaan manufaktur yang terdaftar di Indeks Kompas100 periode 2012-2016. Hal ini sejalan dengan teori sinyal yang menjelaskan bahwa manajamen selalu berusaha untuk mengungkapakan informasi privat yang menurut pertimbangan manajemen sangat diminati oleh investor dan pemegang saham khususnya kalau informasi tersebut merupakan berita baik. jadi penggunaan hutang dapat menjadi sinyal positif yang diberikan perusahaan kepada investor untuk meningkatkan nilai perusahaan dimata investor.

4. Hipotesis ketiga $\left(\mathrm{H}_{4}\right)$ ditolak. Hasil penelitian yang telah dilakukan, dari persamaan regresi sederhana pada model analisis untuk hipotesis keempat menyatakan bahwa hasil uji t (uji parsial) memberikan informasi bahwa likuiditas secara parsial tidak berpengaruh dan tidak signifikan terhadap Nilai Perusahaan. Dengan menggunakan rasio aktivitas dapat mengukur sejauh mana perusahaan mempergunakan sumber daya yang dimilikinya guna menunjang aktivitas perusahaan. Semakin besar tingkat rasio aktivitas maka semakin baik kinerja perusahaan dalam pengelolaan asetnya. Rasio aktivitas dalam penelitian diukur menggunakan Inventory Turn Over. Rasio ini menggambarkan hubungan antara tingkat penjualan (sales) dengan sediaan (Inventory) yang dibutuhkan untuk menunjang kegiatan operasi perusahaan tersebut. Semakin besar Inventory Turn Over. maka aktiva dapat lebih cepat berputar dan meraih laba yang menunjukkan semakin efisien penggunaan keseluruhan aktiva dalam menghasilkan penjualan. Hasil penelitian didapat bahwa kinerja keuangan dengan rasio aktivitas tidak berpengaruh terhadap nilai perusahaan dapat diartikan bahwa perusahaan kurang efektif dan efisien dalam mengelola persediaan atas penjualan. Sejalan penelitian terdahulu Faldy G. Lumentut, Marjam Mangantar (2017), Hasil penelitian ini membuktikan bahwa secara parsial likuiditas dan profitabilitas tidak berpengaruh terhadap nilai perusahaan manufaktur sedangkan solvabilitas dan aktivitas secara parsial berpengaruh terhadap nilai perusahaan manufaktur yang terdaftar di Indeks Kompas100 periode 2012-2016. Hal ini sejalan dengan teori sinyal menjelaskan bahwa perusahaan melaporkan informasi bisnis kepada stakeholder, informasi tersebut bisa berupa nilai perusahaan yang di pengaruhi oleh kinerja keuangan perusahaan. 
informasi perusahaan yang berupa nilai perusahaan akan bermanfaat bagi stakeholders dalam membuat keputusan, terutama kreditur dan investor. Dengan melihat kinerja keuangan kreditur akan mempertimbangkan keputusan dalam meminjamkan modal kepada perusahaan, sedangkan kinerja keuangan perusahaan bagi investor berguna untuk sebagai bahan pertimbangan dalam mengambil keputusan dalam berinvestasi.

5. Hipotesis Kelima (H5) ditolak. Hasil penelitian berdasarkan persamaan regresi sederhana pada model analisis untuk hipotesis kelima menyatakan bahwa hasil uji $\mathrm{t}$ (uji parsial) memberikan informasi bahwa likuiditas secara parsial tidak berpengaruh dan tidak signifikan terhadap Nilai Perusahaan. Rasio profitabilitas digunakan untuk menilai kemampuan perusahaan dalam menghasilkan laba. Rasio ini juga menjadi tolak ukur efisiensi menajemen perusahaan. Hal ini tercermin dari keuntungan penjualan dan pendapatan investasi. Intinya yaitu penggunaan rasio ini menunjukkan efisiensi perusahaan. "Penggunaan rasio profitabilitas dapat dilakukan dengan menggunakan perbandingan antara laba bersih setelah pajak dengan modal sendiri atau Equitas yang ada di laporan keuangan, terutama pada laporan posisi keuangan dan laba rugi". Pengukuran dapat dilakukan untuk beberapa periode operasi. Tujuannya adalah agar terlihat perkembangan perusahaan dalam rentang waktu tertentu, baik penurunan atau kenaikan, sekaligus mencari penyebab perubahan tersebut. Sejalan dengan penelitian terdahulu Faldy G. Lumentut, Marjam Mangantar (2017), Hasil penelitian ini menunjukkan bahwa secara parsial likuiditas dan profitabilitas tidak berpengaruh terhadap nilai perusahaan manufaktur. Hal ini sejalan dengan teori sinyal, yang menjelaskan bahwa para eksekutif perusahaan yang lebih memahami perusahaan akan meneruskan informasi ini kepada calon investor dan menjelaskan kenaikan harga saham perusahaan. Profitabilitas adalah kemampuan perusahaan untuk memperoleh keuntungan. Keuntungan perusahaan berasal dari penjualan dan investasi. Profitabilitas juga menjelaskan kinerja operasional perusahaan. Semakin tinggi tingkat pengembalian ekuitas, semakin tinggi profitabilitas perusahaan. Nilai laba perusahaan yang tinggi memberikan sinyal positif kepada investor dan kreditor bahwa perusahaan dalam keadaan baik dan dengan demikian menarik investor untuk memiliki saham diperusahaan tersebut. Ketika permintaan saham tinggi, investor menilai saham sehingga nilainya lebih tinggi dari nilai rekor perusahaan yang mengakibatkan nilai perusahaan tinggi.

\section{PENUTUP}

\subsection{Kesimpulan}

Membuktikan secara empiris pengaruh kinerja keuangan perusahaan dengan rasio keuangan terhadap nilai perusahaan adalah tujuan dari penelitian ini. Sampel yang digunakan adalah 13 perusahaan Logam dan sejenisnya selama tahun 2016-2019. Maka dapat disimpulkan bawah:

1. Kinerja keuangan perusahaan dengan rasio likuiditas, rasio solvabilitas, rasio aktivitas dan rasio profitabilitas berpengaruh terhadap nilai perusahaan.

2. Kinerja keuangan perusahaan dengan rasio likuiditas berpengaruh terhadap nilai perusahaan. 
JRNAL ПММАH

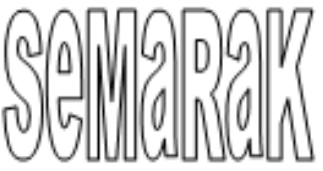

3. Kinerja keuangan perusahaan dengan rasio solvabilitas berpengaruh dan signifikan terhadap nilai perusahaan.

4. Kinerja keuangan perusahaan dengan rasio aktivitas tidak berpengaruh terhadap nilai perusahaan.

5. Kinerja keuangan perusahaan dengan rasio profitabilitas tidak berpengaruh terhadap nilai perusahaan.

\subsection{Saran}

Peneliti memberikan saran berdasarkan keterbatasan diatas, sebagai berikut:

1. Kepada peneliti selanjutnya disarankan untuk melakukan perluasan variabel yang diperkirakan mempengaruhi nilai perusahaa guna memperoleh penjelasan lebih baik mengenai fenomena tersebut. Serta memperluas objek penelitian, dan menggunakan data perusahaan yang terdaftar di bursa efek Indonesia dengan menambah periode tahun penelitian sehingga dapat membandingkan hasil penelitian dengan sebelumnya.

2. Bagi Perusahaan Untuk meningkatkan nilai perusahaan, perusahaan hendaknya meningkatkan dan pempertahankan likuiditas, mampu meningkatkan solvabilitas, kinerja keuangan perusahaan dengan rasio aktivitas dapat lebih efektif dan efisien, serta kinerja keuangan dengan profitabilitas perusahaan dapat meningkatkan ats penghasilan atau laba pada setiap periode. Agar nilai perusahaan terus meningkat dan bertahan maka perusahaan perlu memperhatikan kinerja keuangan secara maksimal pada setiap periodenya.

\section{DAFTAR PUSTAKA}

Aditya Permana, Rahyuda (2019), Vol. 8, No. 3, 2019: 1577 - 1607, ISSN: 23028912, Pengaruh Profitabilitas, Solvabilitas, Likuiditas, Dan Inflasi Terhadap Nilai Perusahaan.

Akhmad, Helmi Muslim Nur, (2014), Vol. 01 No. 02, ISSN 2339-1502, Analisis Rasio Aktivitas Untuk Menilai Kinerja Keuangan Pada Toko Libra Comindo Media Komputer Di Kecamatan Masamba Kabupaten Luwu Utara.

Ayu Nur Indriani (2018), Volume 15, Nomor 1, 2018 Analisis Kinerja Keuangan Perusahaan Yang Terdaftar Di Bursa Efek Indonesia (Bei) Sebelum Dan Sesudah Akuisisi.

Baldric Siregar, Bambang Suripto, Eko Widodo. (2013) Akuntansi Manajemen. Salemba Empat.

Dedi Suhendro Vol. III, No. 1, 2018: 482- 506, Analisis Penilaian Kinerja Keuangan Perusahaan Menggunakan Rasio Keuangan Pada Pt Unilever.

Diah Ika Murtizanah dan Kirwani (2013), Analisis Pengaruh Rasio Likuiditas Dan Rasio Aktivitas Terhadap Profitabilitas Kpri "Makmur" Krian

Dwi Astutik VOL 9 No. 1 Edisi Februari 2017 ( ISSN : 2085-5656) Pengaruh Aktivitas Rasio Keuangan Terhadap Nilai Perusahaan (Studi Pada Industri Manufaktur)

Faldy G. Lumentut, Marjam Mangantar (2017). ISSN 2303-1174, Pengaruh Likuiditas, Profitabilitas, Solvabilitas, Dan Aktivitas Terhadap Nilai Perusahaan Mannufaktur Yang Terdaftar Di Indeks Kompas100 Periode 2012-2016.

Ghozali, H.I. (2018). Aplikasi Analisis Multivariate Dengan Program IBM 
JRNAL ПMПAH

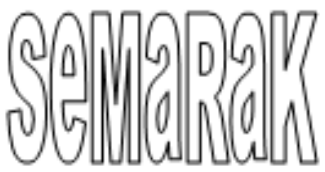

SPSS 25. Semarang: Badan Penerbit Universitas Diponogoro.

Kasmir. (2017). Analisis Laporan Keuangan. Jakarta : PT Raja Grapindo Persada

Melissa, Sabijono, Walandouw (2015) ISSN 2303-11 Vol.3 No.3 Sept. 2015 Analisis Laporan Keuangan Dalam Mengukur Kinerja Keuangan Pada Pt. Bank Artha Graha Internasional, Tbk. Fakultas Ekonomi Universita Sam Ratulangi Manado.

Purnomo, S., \& Pasaribu, V. L. D. (2019). Pergerakan Harga Saham Pt Adaro Energy Tbk (Adro) Pada Pengumuman Dividen Interim Tahun Buku 2018. Jurnal Ekonomi Efektif, 2(1).

Rachmalia Harmdika Putri,Zahroh Z.A., Maria Goretti Wi Endang N.P. , (JAB)|Vol.38 No.2 September 2016|, Pengaruh Rasio Likuiditas Dan Rasio Profitabilitas Terhadap Nilai Perusahaan.

Ratih Puspitasari (2018) Analisa Laporan Keuangan Guna Mengukur Kinerja Keuangan Pt Astra Internasional Tbk.

Riana, Murni, Van Rate (2017). Analisis of Company Financial Performance. Fakultas Ekonomi Universita Sam Ratulangi Manado.

SUTIMAN, S. (2020). PENGARUH SET PELUANG INVESTASI, RASIO PEMBAYARAN DIVIDEN DAN BEBAN KEUANGAN TERHADAP PRICE BOOK VALUE PADA PERUSAHAAN MANUFAKTUR YANG TERDAFTAR DI BURSA EFEK INDONESIA PERIODE 20122016. JURNAL SeMaRaK,3(1), 2740.
Sugiyono (2017), Metode Penelitian Kuantitatif, Kualitatif dan kombinasi (Mixed Methods)

Wartono, T., Tumanggor, M., Oktrima, B., \& Delimah, V. L. (2021, January). Analysis of Ratio and Financial Performance of Open Company Pharmaceutical Industry Which has Been Listing in Indonesia Stock Exchange (Case Study in Pharmaceutical Company PT. Kimia Farma. Tbk). In INCEESS 2020: Proceedings of the 1st International Conference on Economics Engineering and Social Science, InCEESS 2020, 17-18 July, Bekasi, Indonesia (p. 268). European Alliance for Innovation.

Wibowo. (2010). Pengaruh Pengungkapan Laporan Sosial dan Lingkungan Perusahaan terhadap Harga Saham. Fakultas Ekonomi Universitas Diponegoro. Semarang

Wing Wahyu Winarno (2015) Analisis Ekonometrika dan Statistik. Yogyakarta: Palagan Tentara Pelajar 